\title{
Evaluation of Stable Isotopes of Water to Determine Rainwater Infiltration in Soils under Conservation Reserve Program
}

\author{
Timothy S. Goebel, Robert J. Lascano, Veronica Acosta-Martinez \\ USDA-ARS Wind Erosion and Water Conservation Unit, Lubbock, TX, USA \\ Email: Robert.Lascano@ars.usda.gov
}

How to cite this paper: Goebel, T.S., Lascano, R.J. and Acosta-Martinez, V. (2016) Evaluation of Stable Isotopes of Water to Determine Rainwater Infiltration in Soils under Conservation Reserve Program. Journal of Agricultural Chemistry and Environment, 5, 179-190.

http://dx.doi.org/10.4236/jacen.2016.54019

Received: September 13, 2016

Accepted: October 31, 2016

Published: November 3, 2016

Copyright $\odot 2016$ by authors and Scientific Research Publishing Inc. This work is licensed under the Creative Commons Attribution International License (CC BY 4.0).

http://creativecommons.org/licenses/by/4.0/

\begin{abstract}
The Conservation Reserve Program (CRP) is a USDA program introduced in 1985 to reduce soil erosion by increasing vegetative cover of highly erodible land. Participation in the CRP is done via contracts (10 - 15 years in length) and currently the total area of land under contract is set to decline as per the 2014 Farm Bill. The Texas High Plains (THP) leads the US with $>900,000$ ha enrolled in CRP. A potential longterm benefit of CRP is to increase soil organic matter and to improve soil structure leading to increased water infiltration. Our objective was to evaluate the feasibility of using stable isotopes of water to measure and compare infiltration of rain in land under CRP management to land under continuous dryland cotton in the THP. For this purpose we selected two sites, with soils in the Amarillo series, enrolled in CRP, one for 25 years and the second site for 22 years. Results from several rain events showed that stable isotopes of water are a method that can be used to evaluate the depth of rainwater infiltration for soils under CRP and dryland management.
\end{abstract}

\section{Keywords}

Conservation Reserve Program, Rain, Infiltration, Stable Isotopes, Dryland Cotton

\section{Introduction}

The THP is characterized by frequent droughts and a semiarid climate where annual average rain is about $440 \mathrm{~mm}$ and annual potential evapotranspiration is about six times the average rainfall [1] [2]. In addition, the monthly coefficient of variation for rain is $>70 \%$ and during the crop growing period, from May to September, $\sim 49 \%$ of the rain events are $<10 \mathrm{~mm}$ and these events tend to be of high intensity and of short duration [3]. In the THP the combination of frequent droughts and rainfall patterns that are 
subject to runoff is problematic for dryland agriculture where the only source of water for crop production is from effective rain, i.e., net water stored in the soil. The harvest of rainwater for agriculture in dry regions is a subject of much research, and of interest is to determine agronomic management practices that may lead to increase infiltration of rain [4] [5].

The Conservation Reserve Program (CRP) was introduced in 1985 to reduce soil erosion by converting highly erodible land from agricultural production to native grassland. The CRP has numerous benefits including increased carbon sequestration and microbial diversity through the conversion of highly erodible cropland to grasslands [6] [7]. An additional effect of returning a field to native grassland over an extended period of time is to increase rainwater infiltration. We speculate that this increase may be due to a buildup of soil organic matter leading to an improved soil structure conducive to reduce water runoff from rain events of high intensity and of short duration, which are prevalent in the THP. However, the rate and magnitude of changes in soil physical properties and in soil organic matter varies and the factors that impact these changes are not well known [8]. The 2014 Farm Bill replaced the previous 13 million ha enrollment cap for CRP with limits declining to 10 million ha in 2017 and 2018. Each year, expiring CRP contracts results in the conversion of restored CRP land back to cropland. This trend is potentially reversing multiple ecological benefits of CRP including reduced soil erosion as well as carbon sequestration potential and microbial biodiversity [6] [7].

An additional factor to consider in the management of dryland cropping systems on the THP is the effects of climate change, which has been suggested to cause an increase in the intensity of rain events [9]. The intensity of these rain events generally leads to runoff of the rainwater and the amount of above ground biomass is a critical component that affects runoff. In the THP, the soil surface of dryland production systems remains bare for most of the year except for the portion of the growing season where soil surface coverage varies depending on crop type and rain received. On a bare soil, rainwater runoff is due to the rapid saturation of the soil surface causing swelling of the clay particles that slow the infiltration rate of additional rainfall. This leads to runoff to surrounding and adjacent low areas such as drainage ditches or playa lakes and is water that is not available for crop production [6]. The amount of runoff might be decreased through conversion of agricultural fields into grassland through the CRP program. However, the impact of these potential benefits is not well characterized [6]. Therein, the importance of understanding the long-term impacts of CRP and how it affects the water balance of dryland production systems in the THP.

The traditional field method to measure water infiltration is by using different types of infiltrometers, i.e., single and double ring [10] [11], tension disc and pressure ring [12]. These measurements are subject to effects due to soil cracks, soil crust, earthworm holes and root channels, and to soil tillage management practices. Another method is to use rainfall simulators [13] [14]. The theory and practice of tension disc and ring infiltrometers is well established; however, the method is laborious and time-consuming. 
An alternative method that has emerged in hydrology is the use of stable isotopes of water [15]-[17]. This method operates under the principle that rainwater has a different isotopic signature than the soil water that is under static conditions prior to a given rain event. The traditional methods to measure water infiltration can determine the depth of water infiltration for a given rain event but they cannot differentiate water present in the soil before the rain from the actual rainwater. However, using stable isotopes of water allows the differentiation of soil water from rainwater. One method of identifying the isotopic concentration of soil water is through cryogenic distillation [18]. This method requires the removal of all of the water in a soil sample prior to analysis. By taking advantage of the fact that cryogenic distillation effectively dries a soil sample, the soil gravimetric water content can be simultaneously obtained while extracting the soil water for isotopic analysis. Using both gravimetric and isotopic techniques the depth of soil water content changes can be identified gravimetrically and the difference in $\delta^{18} \mathrm{O}$ (\%) ratios from soil samples taken before and after rain events can determine the depth of rainwater infiltration [19] [20]. Ideally, the gravimetric water can be converted to a volume basis knowing the corresponding bulk density of the soil.

Infiltrometers measure the infiltration rate but do not account for runoff. However, using stable isotopes of water allows tracking the depth of infiltration of the rainwater and comparing runoff to adjacent fields, i.e., CRP vs. bare soil. The objective of this study was to investigate the feasibility of using stable isotopes of water to measure the depth of infiltration of rainwater for a soil series (Amarillo Fine Sandy Loam) under dryland cotton production and CRP. The fields under these two management practices were adjacent to each other and were selected to minimize variability in rainfall between the two sites.

\section{Materials and Methods}

\subsection{Site Description}

Two sites were chosen for this study with similar soil types and with more than 24 years under CRP contract. One site was in Lynn County TX where the soil was an Amarillo (Fine-loamy, mixed, superactive, thermic Aridic Paleustalfs) soil series that spanned across both the dryland and CRP fields (Figure 1(A) and Figure 1(B)) located $17.3 \mathrm{~km}$ west of Tahoka TX. This site has been under CRP for 24 years enrolling in 1992. The second site was located in Terry County TX also classified as an Amarillo soil series that spanned from a dryland field across a road into an adjacent CRP field (Figure 1(C) and Figure 1(D)) located $12.5 \mathrm{~km}$ east of Brownfield TX. This site enrolled in CRP in 1985 and thus has been under CRP management for 31 years.

\subsection{Rainfall Events}

Due to the extreme drought in the THP during the study period there were few rain events and most of these events produced $<10 \mathrm{~mm}$ of water (Figure 2). At each site, rainwater was collected with a plastic rain gauge (Model 260-2531M, Nova Lynx Corp., Auburn CA), where $\sim 5 \mathrm{~mL}$ of mineral oil was added prior to any rain. The mineral oil 


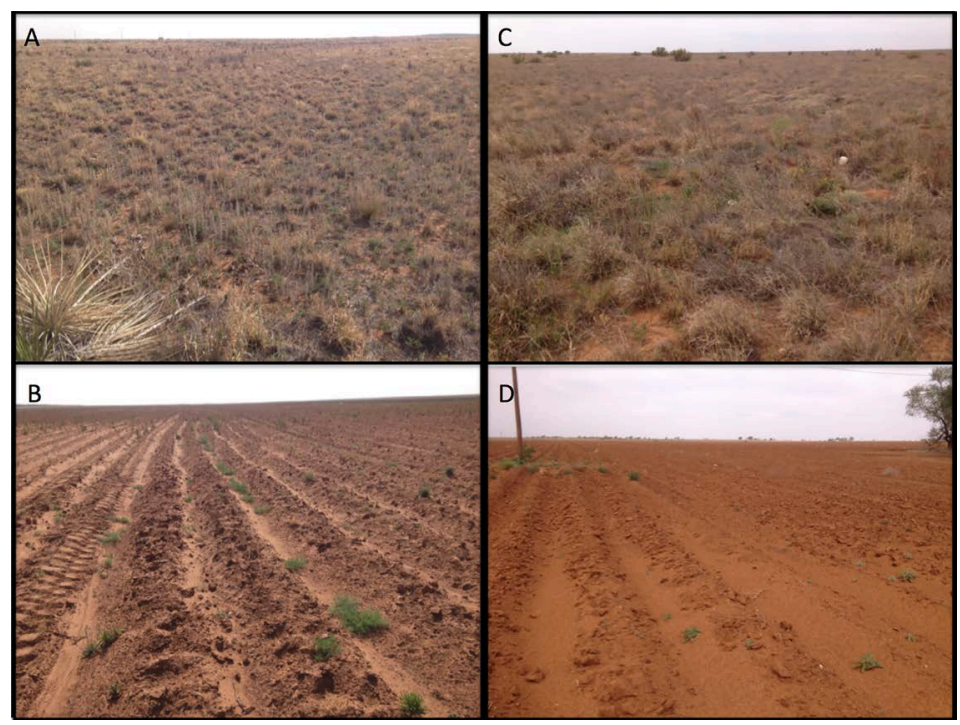

Figure 1. Images of field sites used for the study. (A) CRP site in Lynn County, and (B) adjacent dryland cotton field in Lynn County; (C) CRP site in Terry County, and (D) adjacent dryland cotton field in Terry County.

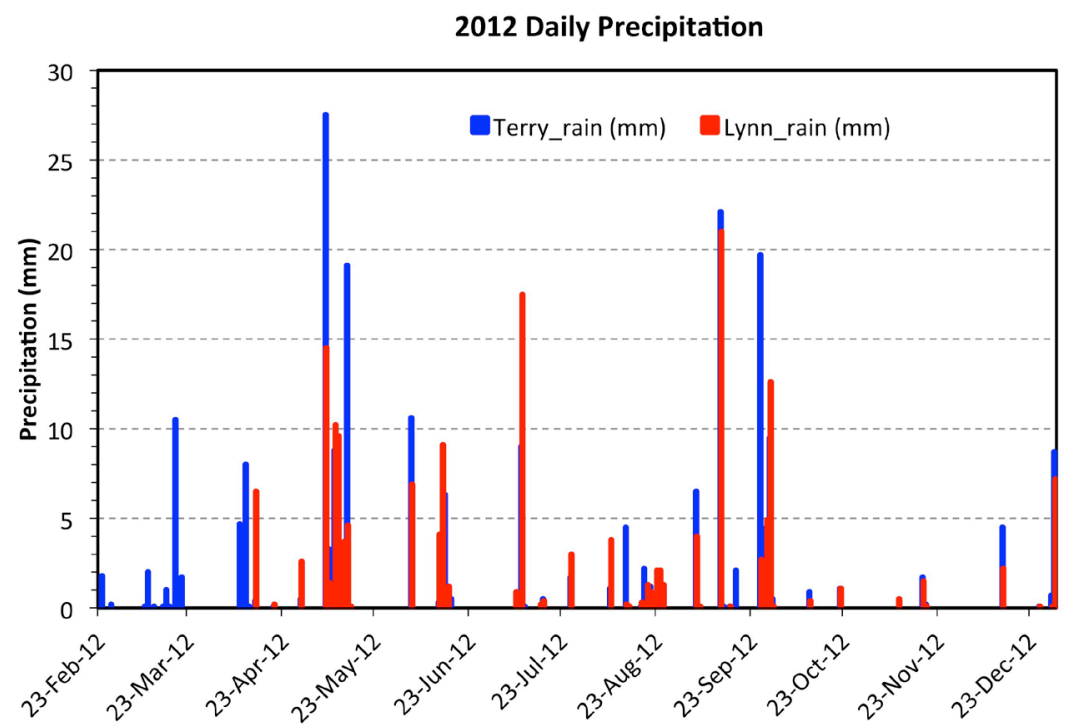

Figure 2. Daily rainfall amounts ( $\mathrm{mm})$ measured at Terry and Lynn County locations from February to December 2012.

acts as a barrier to evaporation of the rainwater and thereby maintains the isotopic concentration until the rainwater was collected in a vial and sealed for storage. In Lynn County the two largest rain events were recorded between the 7 and 14 May 2012 with accumulations of $44 \mathrm{~mm}$ and the largest individual rain event during this period was $14.4 \mathrm{~mm}$ (Figure 2). The daily air temperature range for the 7 May was a low of $13.9{ }^{\circ} \mathrm{C}$ and a high of $24.4{ }^{\circ} \mathrm{C}$, and on the 14 May the low was $11.7^{\circ} \mathrm{C}$ and the high was $17.2^{\circ} \mathrm{C}$. The second largest rain event occurred 13 September 2012 with a total accumulation of $21 \mathrm{~mm}$ (Figure 2) with a daily air temperature range from a low of $12.2{ }^{\circ} \mathrm{C}$ to a high of 
$18.9^{\circ} \mathrm{C}$. For Terry County, rain events were recorded from the 7 to 14 May 2012 with accumulations of $68 \mathrm{~mm}$ with the largest individual rain event of $27.5 \mathrm{~mm}$. On the 7 May the daily air temperature ranged from a low of $13.9^{\circ} \mathrm{C}$ to a high of $24.4{ }^{\circ} \mathrm{C}$ and on the 14 May the air temperature ranged from a low of $11.1{ }^{\circ} \mathrm{C}$ to a high of $17.8{ }^{\circ} \mathrm{C}$. Another large rain event occurred on 13 September 2012 with accumulations of $22 \mathrm{~mm}$ (Figure 2) and with a daily air temperature range from a low of $12.2^{\circ} \mathrm{C}$ to a high of $17.2^{\circ} \mathrm{C}$. The values of air temperature were calculated with the algorithm given by [3].

\subsection{Soil Sampling}

Soil sampling was done every 4 - 6 weeks until a rainfall event occurred, thereafter soil sampling was done approximately 3 days later. The pre-rain soil samples represented the soil environment under a stable condition without any rainwater input. The soil samples were collected using a hydraulic soil sampler (Model GSRTS, Giddings Machine Sampler, Windsor CO) mounted on a tractor. A 25-mm soil core was sampled down to a depth of $2.4 \mathrm{~m}$. The soil cores were then processed in the field by cutting them into $0.01-\mathrm{m}$ subsamples to a depth of $0.3 \mathrm{~m}$ and thereafter fourteen $0.15-\mathrm{m}$ subsamples were taken to a depth of $2.4 \mathrm{~m}$. Due to the accumulated number of soil samples from sampling all four sites at a single time only one core was taken per field per sampling day to represent the entire field. The soil from these subsamples were then placed directly into pre-weighed ignition tubes and sealed with rubber stoppers and placed in a cooler. Thereafter, samples were placed in a freezer for storage until they were extracted by vacuum distillation. The extraction method used was cryogenic vacuum distillation [18]. The samples were removed from the freezer and placed in liquid nitrogen for 20 minutes to assure they were completely frozen. The ignition tube containing the soil sample was then placed on the cryogenic distillation apparatus and the extraction was allowed to progress for 60 minutes as described in [18]. The water collected from the distillation was then sealed with Parafilm ${ }^{\circledR}$, placed in a water bath, and allowed to thaw. The liquid water was then placed in a $2 \mathrm{~mL}$ vial and analyzed using the Liquid Water Isotope Analyzer (Model DLT-100, Los Gatos Research, Mountain View CA) to determine the isotopic composition of the soil water and analyzed using the International Atomic Energy Agency (IAEA) protocol for isotopic analysis of liquid water [21].

\section{Results and Discussion}

This study was conducted during 2012 and 2013, which was among the driest years due to a prolonged drought in the THP, resulting in soil gravimetric water contents of $<5 \%$ in the surface $0.1 \mathrm{~m}$ and water contents of less than $10 \%$ to a depth of $0.3 \mathrm{~m}$ (Figures 3-6). Due to this drought there were few significant large rain events, and the single rain largest event was $27.5 \mathrm{~mm}$ on 7 May 2012 in Terry County (Figure 2). The presentation of results is done by County and it follows.

\subsection{Lynn County}

The total rainfall amounts were lower in Lynn County during the study period with the 
Results from soil cores taken from a field in Lynn County under dryland cotton management before and after a 21-mm rain event. Gravimetric Water Content (\%)

$\delta^{18} \mathrm{O}(\%)$ of Soil Water
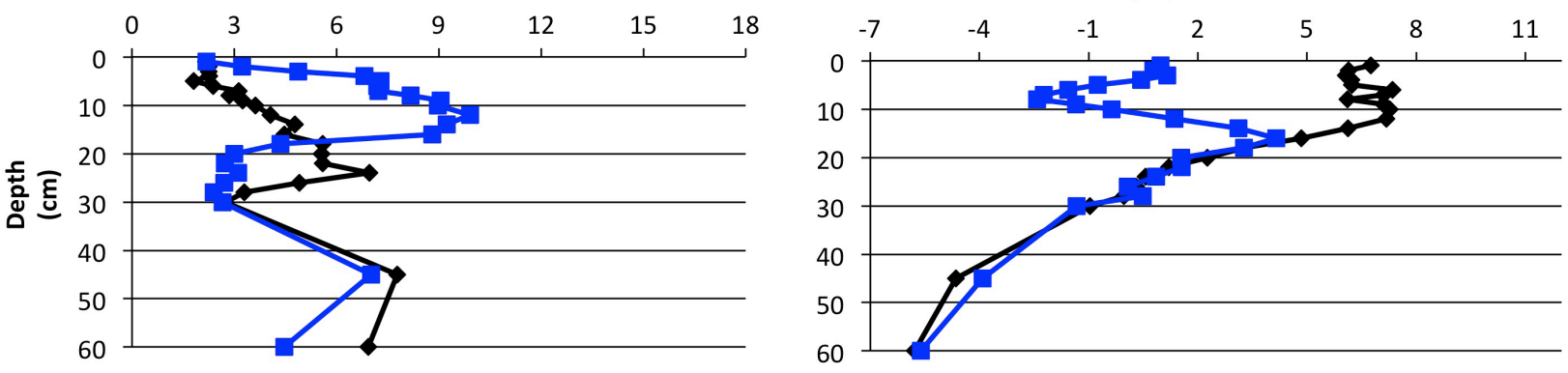

Results from soil cores taken from a field in Lynn County under CRP management before and after a 21-mm rain event. Gravimetric Water Content (\%)
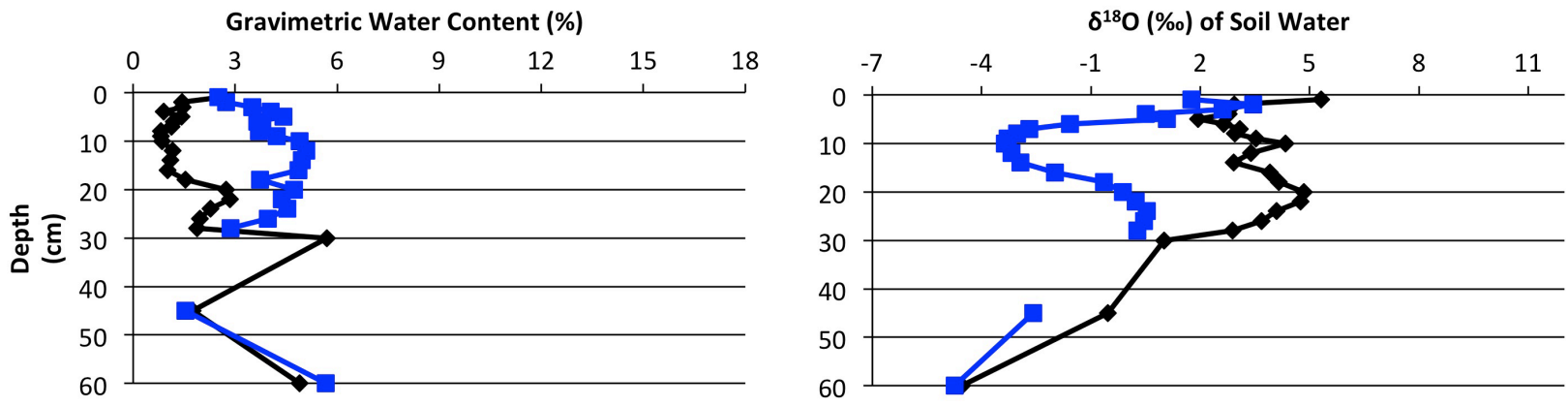

Figure 3. Measured soil gravimetric water content and water isotopic data for dryland and CRP fields in Lynn County to a depth of $0.6 \mathrm{~m}$ before the 25 August 2012 (Black) and after the 18 September 2012 (Blue). During this period a 21-mm rain event was measured at the site.

Results from soil cores taken from a field in Lynn County under dryland cotton management before and after a 43 -mm rain event. Gravimetric Water Content (\%) $\delta^{18} \mathrm{O}(\%)$ of Soil Water
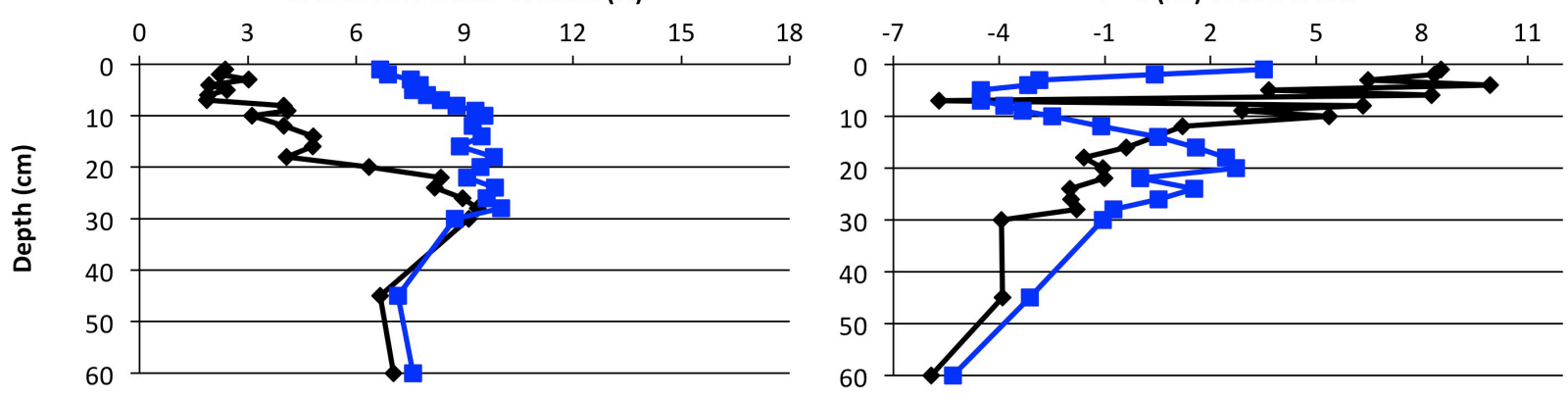

Results from soil cores taken from a field in Lynn County under CRP management before and after a 43 -mm rain event.
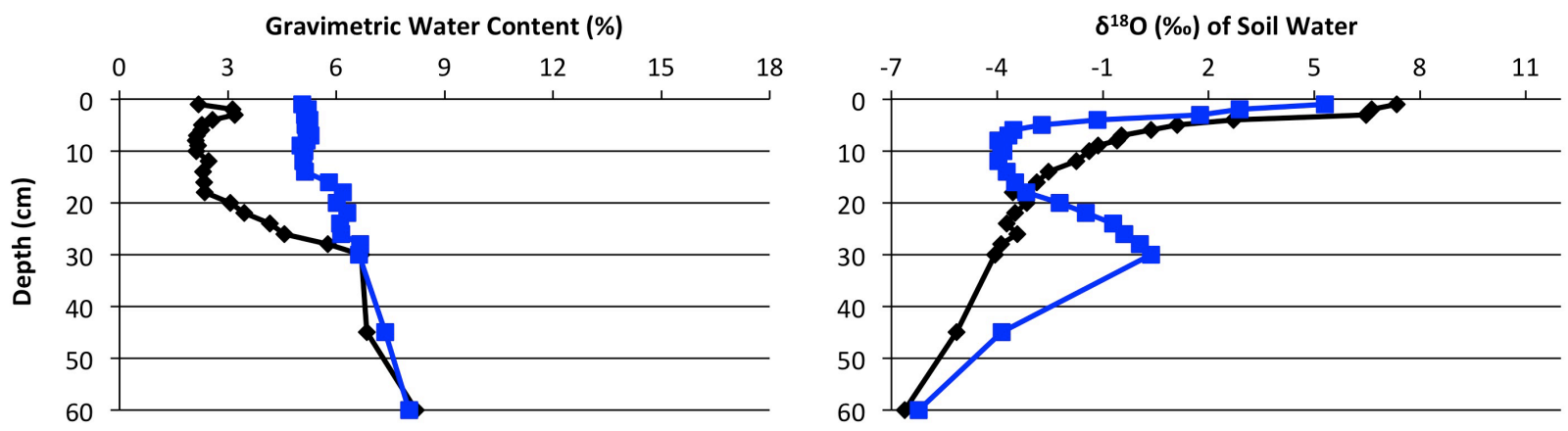

Figure 4. Measured soil gravimetric water content and water isotopic data for dryland and CRP fields in Lynn County to a depth of $0.6 \mathrm{~m}$ before the 20 April 2012 (Black) and after the 17 May 2012 (Blue). During this period a 43-mm rain event was measured at the site. 
Results from soil cores taken from a field in Terry County under dryland cotton management before and after a 22-mm rain event. Gravimetric Water Content (\%)

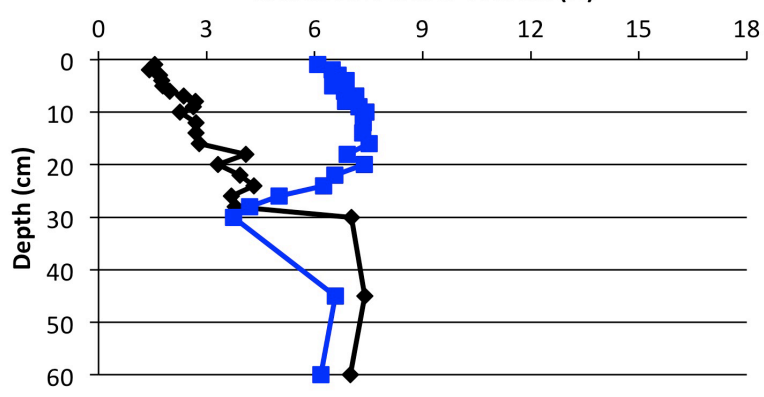
$\delta^{18} \mathrm{O}(\%)$ of Soil Water

Results from soil cores taken from a field in Terry County under CRP management before and after a 22-mm rain event. Gravimetric Water Content (\%)
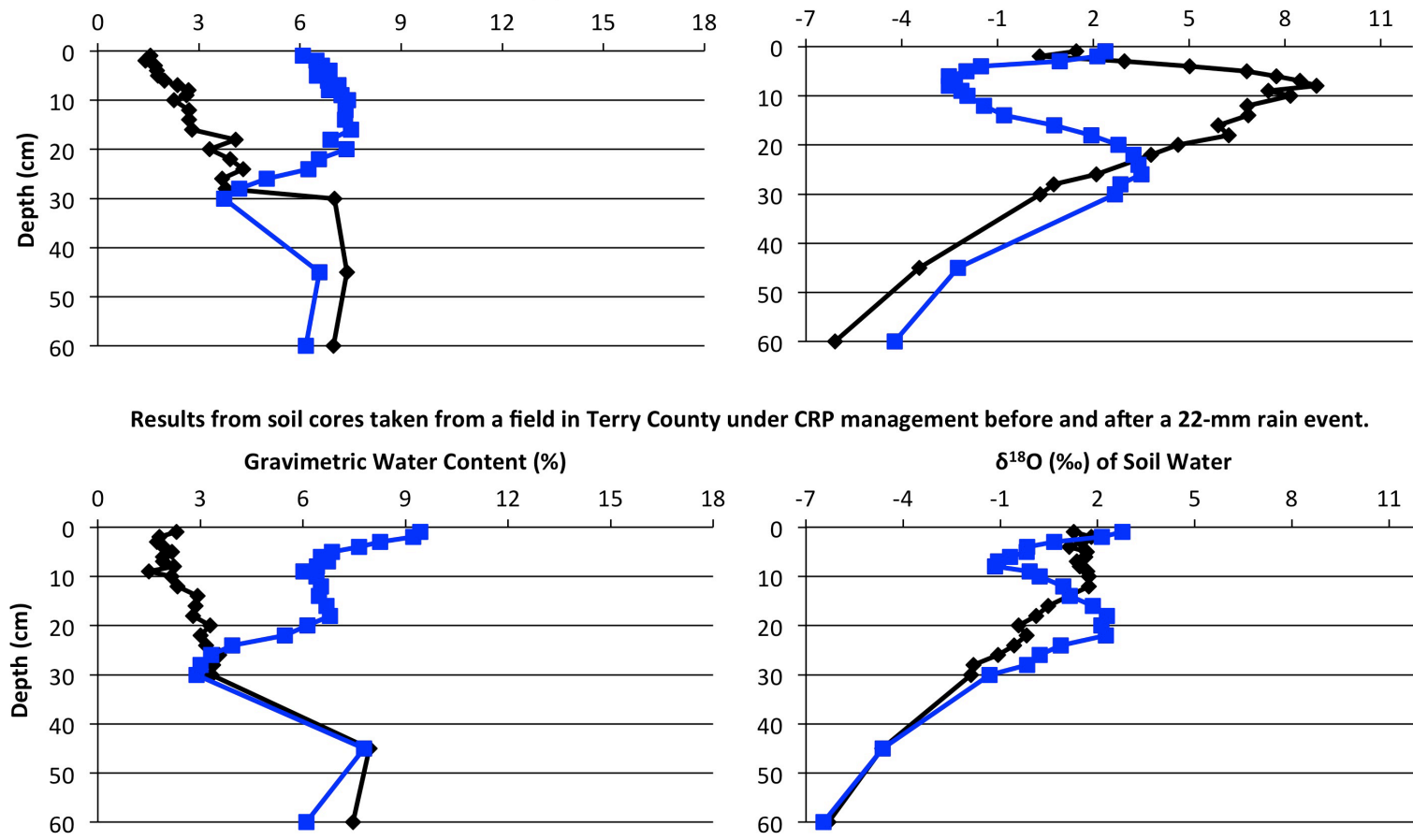
$\delta^{18} \mathrm{O}(\%)$ of Soil Water

Figure 5. Measured soil gravimetric water content and water isotopic data for dryland and CRP fields in Terry County to a depth of $0.6 \mathrm{~m}$ before the 25 August 2012 (Black) and after the 18 September 2012 (Blue). During this period a 22-mm rain event was measured at the site.

Results from soil cores taken from a field in Terry County under dryland cotton management before and after a 68-mm rain event. Gravimetric Water Content (\%)

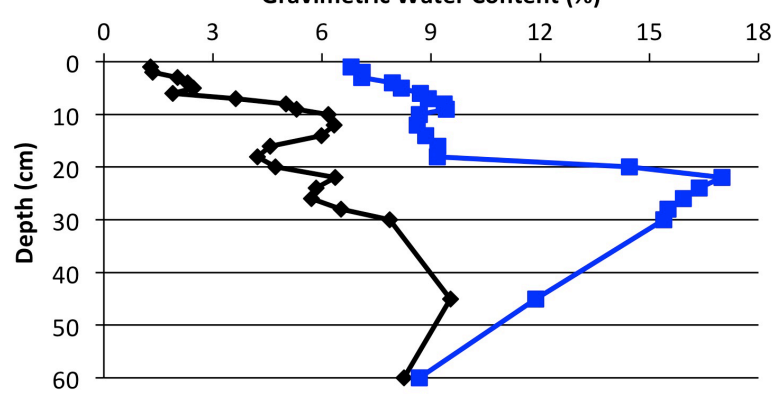
$\delta^{18} \mathrm{O}(\%)$ of Soil Water

Results from soil cores taken from a field in Terry County under CRP management before and after a 68-mm rain event.
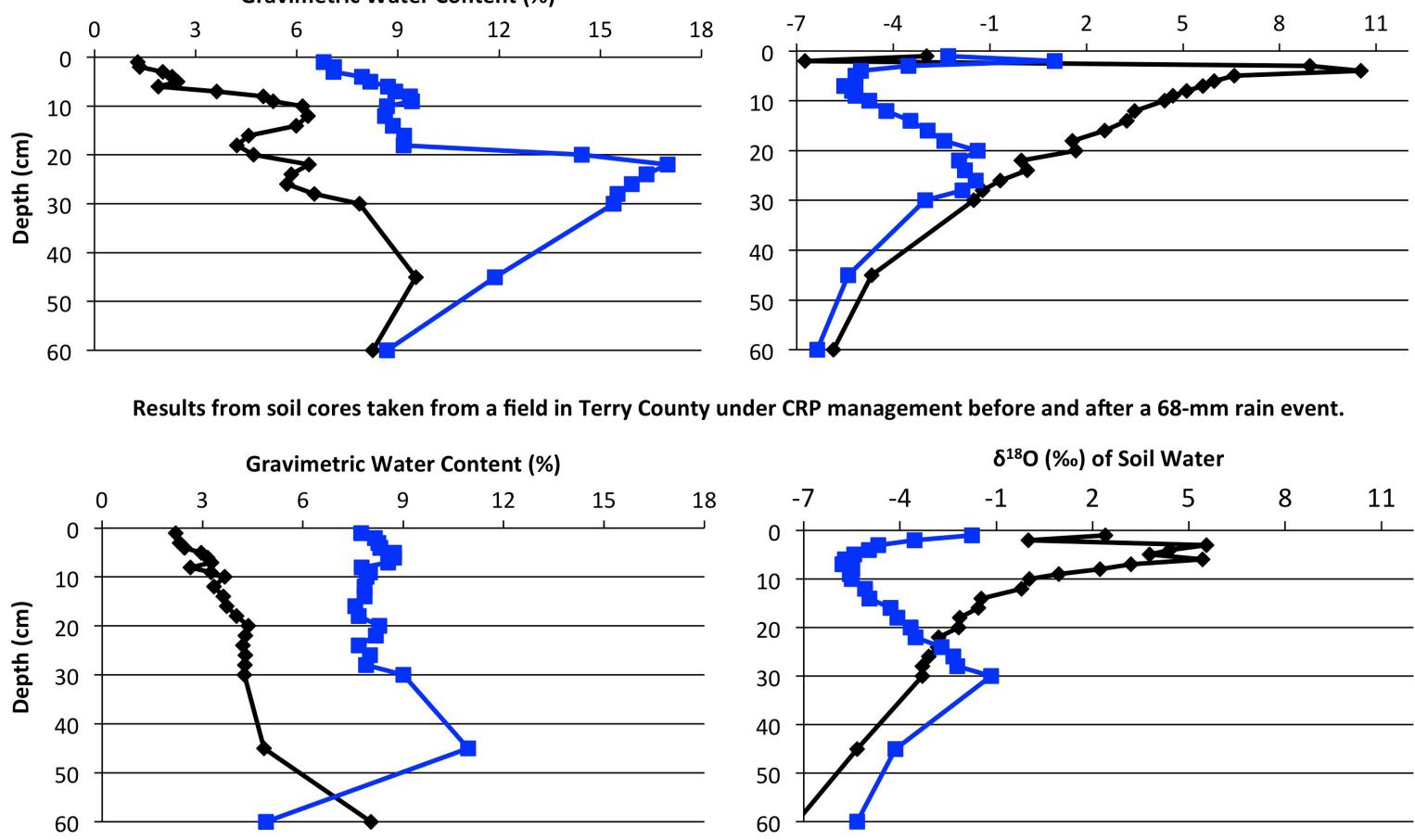
$\delta^{18} \mathrm{O}(\%)$ of Soil Water

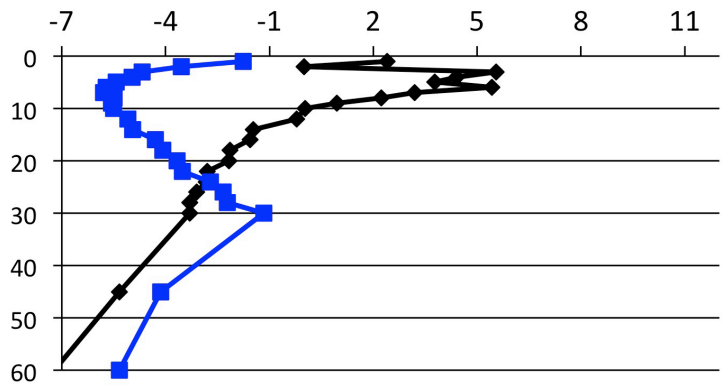

Figure 6. Measured soil gravimetric water content and water isotopic data for dryland and CRP fields in Terry County to a depth of $0.6 \mathrm{~m}$ before the 20 April 2012 (Black) and after the 17 May 2012 (Blue). During this period a 68-mm rain event was measured at the site. 
two largest individual rainfall amounts of $14.4 \mathrm{~mm}$ and $21 \mathrm{~mm}$ (Figure 2). Due to the drought, the soil gravimetric water content was low especially in the upper $0.2 \mathrm{~m}$ with values of less than $10 \%$ and values as low as $3 \%$ closer to the soil surface (Figure 3 and Figure 4). Due to the low soil water content prior to the rain event there was little soil structure, i.e., loose soil, near the surface that caused mixing when the soil cores were inverted prior to being cut and processed for isotopic analysis. The usual isotopic soil water profile for the water present in a bare soil was also not well delineated in the pre-rain sampling due to mixing of the top soil layers during sampling (Figure 3). After the $0.1 \mathrm{~m}$ soil depth, the usual pattern of decreasing isotopic enrichment with soil depth was measured [16] [22] [23]. After the $21 \mathrm{~mm}$ rain event on 13 September 2012 the sampled gravimetric water content showed that rain infiltrated to a soil depth of approximately $0.20 \mathrm{~m}$. The isotopic profile of the soil water after the rain event shows depletion of the soil water in the upper $0.16 \mathrm{~m}$ of the soil profile. This depletion is due to the movement of the rainwater into the soil profile containing highly enriched water at very low volumes. The peak at $0.16 \mathrm{~m}$ and $4.2 \delta^{18} \mathrm{O}(\% \mathrm{o})$ is the point where the dilution of the soil water present ceases and the isotopic composition of the soil water tended to approach that of the pre-rain sample suggesting that rainwater infiltration did not exceed this soil depth (Figure 3 ).

The results from the adjacent field under CRP contract showed a slightly deeper infiltration of rainwater compared to the adjacent dryland cotton field (Figure 3). The results from the gravimetric water content taken from the soil cores showed an increase in water content to a depth of $0.3 \mathrm{~m}$ compared to that of the pre-rain samples. The isotopic data set is missing a data point at $30 \mathrm{~cm}$ due to the sample vial being broken. The isotopic profile of the soil water also suggested that the rainwater did not infiltrate past $0.3 \mathrm{~m}$ with the depletion in isotopic signature above $0.3 \mathrm{~m}$ and approaching similar values to that of the pre-rain sample after a $0.3 \mathrm{~m}$ soil depth.

The pre-rain soil samples taken on 20 April 2012 in the dryland field again illustrate the extreme drought that occurred at the time of sampling with soil gravimetric water contents of less than $5 \%$ down to $0.2 \mathrm{~m}$ and deeper soil water contents not exceeding $10 \%$ (Figure 4). The field had recently been deep plowed and as a result the isotopic profile of the soil water content varied over the first $0.1 \mathrm{~m}$, with the common profile of isotopic depletion with depth resolving after $0.1 \mathrm{~m}$ (Figure 4). Following a week of scattered rain the site had three rain events of 14, 10, and $9 \mathrm{~mm}$ (Figure 2). The measured soil gravimetric water content from the soil cores showed the rainwater infiltrating to $0.30 \mathrm{~m}$ and thereafter approaching similar values to that of the pre-rain samples (Figure 4). The soil cores taken from the adjacent CRP site also showed infiltration to a depth of $0.3 \mathrm{~m} \mathrm{~cm}$ as described by the measured soil gravimetric water content (Figure 4). The isotopic soil profile also showed rainwater infiltration to a depth of $0.3 \mathrm{~m}$ as illustrated by the peak of enrichment of the post-rain at a $0.3 \mathrm{~m}$ depth (Figure 4).

\subsection{Terry County}

The total rainfall amounts were higher for Terry County than for Lynn County over the 
study period with the two largest individual rainfall amounts of $27 \mathrm{~mm}$ on 7 May 2012 and $22 \mathrm{~mm}$ on 13 September 2012 (Figure 2). The results from the soil gravimetric water content again showed the severity of the drought with values less than $10 \%$ to a soil depth of $0.6 \mathrm{~m}$ for both the dryland and CRP fields (Figure 5 and Figure 6). After the $22 \mathrm{~mm}$ rain on 13 September 2012 the soil gravimetric water content showed an increase in water content to a depth of approximately $0.26 \mathrm{~m}$ for both the dryland and CRP fields (Figure 5). The isotopic soil water profile closely resembled the gravimetric results with depletion in the $\delta^{18} \mathrm{O}(\%)$ composition of the soil water due to influx of rainwater (Figure 5). At a soil depth of $0.24-0.26 \mathrm{~m}$ the isotopic profiles converged and showed a similar trend suggesting that rainwater did not infiltrate past this point for either the dryland or CRP field (Figure 5).

The 27-mm rain event that occurred on 7 May 2012 gave different results than those for the 22-mm rain event that occurred later in the year. In this case the soil gravimetric water contents showed an increase in soil water to a depth of $0.45 \mathrm{~m}$ after the rain event (Figure 6). The results from the isotopic soil water profile suggested that the rainwater did not infiltrate past 0.26 and $0.30 \mathrm{~m}$ for the dryland and CRP field sites, respectively (Figure 6).

While the results from individual rain events suggested that using stable water isotopes to determine the depth of rainwater infiltration is useful to a depth of $0.30 \mathrm{~m}$, rainwater infiltration beyond this depth was less obvious. While the isotopic soil water profile past $0.3 \mathrm{~m}$ began to show the pattern observed by [19] [24], the actual values are different for the pre- and post-rain profiles with the post-rain values being more enriched than the pre-rain samples (Figure 6). This difference could be due to mixing of the highly enriched water present in the top $0.3 \mathrm{~m}$ as it was moved deeper into the soil profile instead of through piston type flow; however, the differences could be attributed to natural spatial variation in the stable isotope composition of the soil water across the field. To the best of the authors knowledge the spatial variability of the isotopic soil water profile has not been addressed. Our results suggested that to quantify rainwater infiltration depths using stable isotopes of water it is necessary to determine its spatial distribution. This implies that both rainfall and depth of infiltration have to be measured at adequate densities to describe their spatial distribution. The measurement of rainfall is well-established using rain gauges that measure both rate and amount, but lacking is information regarding the number of samples needed to characterize rainfall distribution across say a 1/4-section of land (65 ha). Conversely, information on the spatial distribution of rainwater infiltration depth is also not available. However, it is possible to obtain information on the spatial distribution of rainwater depth by measuring surrogate soil properties that are easily measured, e.g., soil texture, soil organic content, penetration resistance, soil bulk density, macro-aggregate stability, that are known to impact water infiltration as suggested by [8]. This is a subject matter for future research of our unit.

\section{Conclusion}

As expected, there were small increases in the depth of rainwater infiltration in land 
managed under CRP compared to adjacent dryland cotton fields; however, the rainfall amounts were small so that the differences measured could be simply due to natural variation. On the THP $95 \%$ of the rain events produce $25 \mathrm{~mm}$ of rain or less and as such the results presented here therefore suggested that generally there was little difference in the depth of rainwater infiltration observed under dryland or CRP management. It is likely that for larger rain events the effect of increased soil structure occurring under CRP management would yield deeper rainwater infiltration; however, the spatial variation of isotopic composition of soil water deeper than $0.3 \mathrm{~m}$ should be first defined and this is a topic of further investigation. Nevertheless, our objective was met and we conclude that stable isotopes of water are a method that can be used to determine the depth of rainwater infiltration under field conditions.

\section{Acknowledgements}

This research was supported in part by the Ogallala Aquifer Program, a consortium between USDA Agricultural Research Service, Kansas State University, Texas AgriLife Research, Texas AgriLife Extension Service, Texas Tech University, and West Texas A \& M University.

Mention of trade names or commercial products in this publication is solely for the purpose of providing specific information and does not imply recommendation or endorsement by the U.S. Department of Agriculture.

The U.S. Department of Agriculture (USDA) prohibits discrimination in all its programs and activities on the basis of race, color, national origin, age, disability, and where applicable, sex, marital status, familial status, parental status, religion, sexual orientation, genetic information, political beliefs, reprisal, or because all or part of an individual's income is derived from any public assistance program.

\section{References}

[1] Holman, D., Sridharan, M., Gowda, P., Porter, D., Marek, T., Howell, T. and Moorhead, J. (2014) Gaussian Process Models for Reference ET Estimation from Alternative Meteorological Data Sources. Journal of Hydrology, 517, 28-35. http://dx.doi.org/10.1016/j.jhydrol.2014.05.001

[2] Lascano, R.J. (2000) A General System to Measure and Calculate Daily Crop Water Use. Agronomy Journal, 92, 821-832. http://dx.doi.org/10.2134/agronj2000.925821x

[3] Mauget, S. and Leiker, G. (2010) The Ogallala Agro-Climate Tool. Computers and Electronics in Agriculture, 74, 155-162. http://dx.doi.org/10.1016/j.compag.2010.08.002

[4] Oweis, T.Y., Prinz, D. and Hachum, A.Y. (2012) Rainwater Harvesting for Agriculture in Dry Areas. CRC Press/Balkema, Taylor \& Francis Group, London, UK, 262 p. http://dx.doi.org/10.1201/b12351

[5] Lascano, R.J. and Nelson, J.R. (2014) Circular Planting to Enhance Rainfall Capture in Dryland Cropping Systems at a Landscape Scale: Measurement and Simulation. Advances in Agricultural Systems Modeling, 5, 85-111. http://dx.doi.org/10.2134/advagricsystmodel5.c4

[6] Acosta-Martinez, V., Burow, G., Zobeck, T. and Allen, V. (2010) Soil Microbial Communities and Function in Alternative Systems to Continuous Cotton. Soil Science Society of 
America Journal, 74, 1181-1192. http://dx.doi.org/10.2136/sssaj2008.0065

[7] Acosta-Martínez, V., Klose, S. and Zobeck, T.M. (2003) Enzyme Activities in Semiarid Soils under Conservation Reserve Program, Native Rangeland, and Cropland. Journal of Plant Nutrition and Soil Science, 166, 699-707. http://dx.doi.org/10.1002/jpln.200321215

[8] Franzluebbers, A.J. (2002) Water Infiltration and Soil Structure Related to Organic Matter and Its Stratification with Depth. Soil \& Tillage Research, 66, 197-205. http://dx.doi.org/10.1016/S0167-1987(02)00027-2

[9] Walsh, J., Wuebbles, D., Hayhoe, K., Kossin, J., Kunkel, K., Stephens, G., Thorne, P., Vose, R., Wehner, M. and Willis, J. (2014) Appendix 3: Climate Science Supplement, Climate Change Impacts in the United States: The Third National Climate Assessment. In: Melillo, J.M., Richmond, T. and Yohe, G.W., Eds., US Global Change Research Program, 771.

[10] Johnson, A.I. (1963) A Field Method for Measurement of Infiltration. Geological Survey Water-Supply Paper 1544-F, U.S. Department of Interior, $31 \mathrm{p}$.

[11] Julander, R.P. and Jackson, W. (1983) Drop Former and Double Ring Infiltrometers-A Comparison. In: Advances in Infiltration, American Society of Agricultural Engineers, St. Joseph, 249-253.

[12] Angulo-Jaramillo, R., Vandervaere, J.-P., Roulier, S., Thony, J.-L., Gaudet, J.-P. and Vauclin, M. (2000) Field Measurement of Soil Surface Hydraulic Properties by Disc and Ring Infiltrometers: A Review and Recent Developments. Soil \& Tillage Research, 55, 1-29. http://dx.doi.org/10.1016/S0167-1987(00)00098-2

[13] Morin, J. and Benyamini, Y. (1977) Rainfall Infiltration into Bare Soils. Water Resources Research, 13, 813-817. http://dx.doi.org/10.1029/WR013i005p00813

[14] Sidiras, N. and Roth, C.H. (1987) Infiltration Measurements with Double-Ring Infiltrometers and a Rainfall Simulator under Different Surface Conditions on an Oxisol. Soil \& Tillage Research, 9, 161-168. http://dx.doi.org/10.1016/0167-1987(87)90082-1

[15] Dincer, T., Al-Mugrin, A. and Zimmerman, U. (1974) Study of the Infiltration and Recharge through the Sand Dunes in Arid Zones with Special Reference to the Stable Isotopes and Thermonuclear Tritium. Journal of Hydrology, 23, 79-109. http://dx.doi.org/10.1016/0022-1694(74)90025-0

[16] Barnes, C. and Allison, G. (1988) Tracing of Water Movement in the Unsaturated Zone Using Stable Isotopes of Hydrogen and Oxygen. Journal of Hydrology, 100, 143-176. http://dx.doi.org/10.1016/0022-1694(88)90184-9

[17] Gazis, C. and Feng, X. (2004) A Stable Isotope Study of Soil Water: Evidence for Mixing and Preferential Flow Paths. Geoderma, 119, 97-111. http://dx.doi.org/10.1016/S0016-7061(03)00243-X

[18] Goebel, T.S. and Lascano, R.J. (2012) System for High Throughput Water Extraction from Soil Material for Stable Isotope Analysis of Water. Journal of Analytical Sciences, Methods and Instrumentation, 2, 203-207. http://dx.doi.org/10.4236/jasmi.2012.24031

[19] Allison, G.B. and Hughes, M.W. (1983) The Use of Natural Tracers as Indicators of SoilWater Movement in a Temperate Semi-Arid Region. Journal of Hydrology, 60, 157-173. http://dx.doi.org/10.1016/0022-1694(83)90019-7

[20] Liu, B., Phillips, F., Hoines, S., Campbell, A.R. and Sharma, P. (1995) Water Movement in Desert Soil Traced by Hydrogen and Oxygen Isotopes, Chloride, and Chlorine-36, Southern Arizona. Journal of Hydrology, 168, 91-110. http://dx.doi.org/10.1016/0022-1694(94)02646-S

[21] Newman, B., Tanweer, A. and Kurttas, T. (2009) IAEA Standard Operating Procedure for the Liquid-Water Stable Isotope Analyser, Laser Procedure. IAEA Water Resources Pro- 
gramme.

[22] Allison, G. (1982) The Relationship between ${ }^{18} \mathrm{O}$ and Deuterium in Water in Sand Columns Undergoing Evaporation. Journal of Hydrology, 55, 163-169.

http://dx.doi.org/10.1016/0022-1694(82)90127-5

[23] Braud, I., Biron, P., Bariac, T., Richard, P., Canale, L., Gaudet, J. and Vauclin, M. (2009) Isotopic Composition of Bare Soil Evaporated Water Vapor. Part I: RUBIC IV Experimental Setup and Results. Journal of Hydrology, 369, 1-16.

http://dx.doi.org/10.1016/j.jhydrol.2009.01.034

[24] Goebel, T.S., Lascano, R.J., Paxton, P.R. and Mahan, J.R. (2015) Rainwater Use by Irrigated Cotton Measured with Stable Isotopes of Water. Agricultural Water Management, 158, 17 25. http://dx.doi.org/10.1016/j.agwat.2015.04.005

Submit or recommend next manuscript to SCIRP and we will provide best service for you:

Accepting pre-submission inquiries through Email, Facebook, LinkedIn, Twitter, etc. A wide selection of journals (inclusive of 9 subjects, more than 200 journals)

Providing 24-hour high-quality service

User-friendly online submission system

Fair and swift peer-review system

Efficient typesetting and proofreading procedure

Display of the result of downloads and visits, as well as the number of cited articles

Maximum dissemination of your research work

Submit your manuscript at: http://papersubmission.scirp.org/

Or contact jacen@scirp.org 